\title{
Tadeusz Szczepański
}

ORCID: 0000-0001-8623-4198

PWSFTviT im. L. Schillera w Łodzi

Uniwersytet SWPS w Warszawie

\section{„Oszalał!": Siergiej Eisenstein przygotowuje adaptację Kapitału Karola Marksa}

\begin{abstract}
Abstrakt: Artykuł stanowi analizę legendarnego projektu twórczego Siergieja Eisensteina, który pod koniec lat dwudziestych przymierzał się do sfilmowania Kapitału Karola Marksa. Zamysł ten przez długie lata uchodził za znaną z anegdoty czczą chwalbę wybitnego reżysera, gdy tymczasem w jego dziennikach z lat 1927-1928 można znaleźć materiały, które świadczyły o zaawansowanej pracy koncepcyjnej nad tym filmem. Jej główna idea składała się na pełne rozwinięcie koncepcji tak zwanego kina intelektualnego jako ideologicznego dyskursu, którą Eisenstein częściowo eksperymentalnie realizował w Październiku. Autor artykułu sytuuje robocze zapiski młodego Eisensteina na temat filmowego Kapitału na tle jego zainteresowań marksizmem i w kontekście polityczno-propagandowej ewolucji jego kina w latach dwudziestych, a także wyjaśnia przyczyny porażki tego projektu, którego tematyka i ideologia znalazły pewne refleksy w jego również niezrealizowanych projektach hollywoodzkich.
\end{abstract}

Słowa-klucze: marksizm, Kapitat, kino intelektualne, James Joyce

Wśród potężnego korpusu Eisensteinowskich archiwaliów jeden z najbardziej pasjonujących rozdziałów tworzą scenariusze, które nigdy nie ujrzały światła ekranu, i projekty filmowych realizacji, które nie doszły nawet do fazy scenariusza, pozostając w formie luźnych notatek, zapisków, szkiców i refleksji. Ich lektura nie jest łatwa, ponieważ Eisenstein notował je wyłącznie pro domo sua, posługując się często sobie tylko wiadomym skrótem myślowym i stylistycznym, aluzją i metaforą. Stąd ich narracja jest chaotyczna i fragmentaryczna, pełna niedopowiedzeń, ale dzięki temu znakomicie obrazuje meandryczny bieg myśli koncepcyjnej i artystycznej wyobraźni, ewolucję wizji dzieła, jego status nascendi. Tych niespełnionych, a zdefiniowanych niekiedy bardzo szczegółowo zamysłów było bardzo wiele. Wymieńmy bodaj kilka projektów adaptacyjnych: Kariera Beni Krika według prozy Izaaka Babla, Dola człowiecza André 
Malraux, Bracia Karamazow Fiodora Dostojewskiego czy Tragedia amerykańska Theodore'a Dreisera ${ }^{1}$. A także ten najbardziej sensacyjny i niewiarygodny, znany zaledwie z historycznofilmowej plotki czy anegdoty i przyjmowany na zasadzie dziwacznej ekstrawagancji geniusza: film według Kapitału Karola Marksa. Tymczasem zamiar adaptacji Kapitału nie był gołosłownym wyzwaniem artysty, które mogłoby dowodzić li tylko jego pychy z powodu odkrycia „kamienia filozoficznego" sztuki filmowej. Trudno też posądzać Eisensteina o próżny zamiar epatowania środowiska artystycznej awangardy i jej intelektualnej publiczności, mimo iż takie wrażenie mogą wywoływać świadectwa z tamtej epoki. Wspomina Michaił Blejman:

Siergiej Michajłowicz odstawił szklankę i nieoczekiwanie powiedział, że zamierza sfilmować Kapitat.

- Marksa? - zdziwiłem się.

- Marksa - potwierdził i uchylając się od dalszych wyjaśnień, dalej pił herbatę.

Przyjąłem jego oświadczenie jak polemiczną fantazję. Było polemiczne w stosunku do całej praktyki kina, które było tylko sztuką. A fantazją było dlatego, że nie sposób było nawet pomyśleć o artystycznej realizacji teoretycznego dzieła o takiej skali i takiej złożoności ${ }^{2}$.

Tymczasem ta „polemiczna fantazja” posiadała już dość konkretne zarysy ekranowego kształtu, zanotowane w dziennikach na przełomie lat 1927 i $1928^{3}$ dziennikach, które Eisenstein systematycznie prowadził od 1918 roku aż do śmierci.

Zdawał sobie doskonale sprawę z ogromu i bezprecedensowego charakteru tego przedsięwzięcia, o czym świadczy jego list z 16 grudnia 1928 roku do francuskiego krytyka, Léona Moussinaca:

Anons, że przystąpię do filmowania Kapitału, nie jest żadnym chwytem reklamowym. Sądzę, że na tej drodze znajduje się temat filmu przyszłości [...]. W każdym razie w sferze filozoficznej. Prawdą jest, że podejmę ten temat nie wcześniej niż za rok, za półtora, ponieważ jest to teren zupełnie nietknięty. Tabula rasa. I należałoby zrobić wiele szkiców, zanim można by zmierzyć się z tak olbrzymim tematem i nie narazić się na jego skompromitowanie ${ }^{4}$.

Szokujący na pierwszy rzut oka projekt filmowej adaptacji Marksowskiego Kapitału był wszakże logicznym rezultatem długotrwałej ewolucji artystycznej twórczości Eisensteina, jego światopoglądu filozoficznego i estetycznych koncepcji. Wyobrażone miejsce tego zamysłu w rozwojowej linii jego twórczości dałoby się przenośnie określić matematycznym pojęciem limes, czyli niedosiężnej, abstrakcyjnej granicy poprzedzonej konkretnym ciągiem danych. Idea ta miała swój prolog, na który składały się artystyczne dokonania i teoretyczne lektury.

1 Ich pełną listę można znaleźć w artykule Nauma Klejmana, Nieosuszczestwlionnyje zamysty Ejzensztiejna, „Iskusstwo Kino” 1992, nr 6, s. 9-31.

2 M. Blejman, Plodotwornost',, oszibki”, „Iskusstwo Kino” 1973, nr 1, s. 71.

3 S. Ejzensztiejn, Iz raboczich tietradiej 1927-28 godow, „Iskusstwo Kino” 1973, nr 1, s. 57-67.

${ }^{4}$ L. Moussinac, S. M. Eisenstein, Paris 1964, s. 39.

Prace Kulturoznawcze 22, 2018, nr 3

(C) for this edition by CNS 
Wystarczy przypomnieć rewolucyjną trylogię - Strajk (Staczka, 1924), Pancernik „Potiomkin” (Bronienosiec „Potiomkin”, 1925) i Październik (Oktjabr', 1928) - której generalnym celem była nie tylko filmowa propaganda bolszewickiego przewrotu, ale również jego ideologiczna interpretacja. Rekonstruowane na ekranie fakty rewolucyjnej rzeczywistości podlegały stopniowej ideologizacji kosztem ich falsyfikacji, mitologizacji i hiperbolizacji. W Strajku i w Pancerniku „Potiomkinie” ideologia wynikała z kompozycji zdarzeń. W filmowym debiucie Eisenstein opisał społeczno-klasową strukturę rewolucyjnego konfliktu w jego dynamicznym przebiegu. W Pancerniku „Potiomkinie” reżyser posuwa o krok dalej ideologiczną ingerencję w odtwarzane fakty: film ten prezentuje teleologiczną wizję historii, jego finał ukazuje bowiem - wbrew historycznej prawdzie rekonstruowanego na ekranie zdarzenia — triumfalne zwycięstwo rewolucyjnej idei. Jednakże wyrazem najbardziej radykalnej tendencji do zideologizowania historycznej wizji rewolucji był Październik. W dziele tym interwencja ideologiczna artysty dotyczy nie tylko płaszczyzny mitycznej kompozycji zdarzeń ${ }^{5}$, lecz schodzi na poziom filmowego tworzywa, które ulega znaczeniowej transformacji w procesie montażu - w celu przekształcenia obrazów historycznej rzeczywistości w ikoniczne znaki odsyłające do pojęć historiozoficznego dyskursu.

Nic dziwnego zatem, że pierwszy zapis na temat realizacji Kapitatu znajdujemy w dziennikach Eisensteina pod datą 12 października 1927 roku, czyli w okresie intensywnej pracy nad montażem Października: „Postanowiono zrealizować Kapitat według scenariusza Karola Marksa — jedyne formalne wyjście”. A następnego dnia pisze:

Po dramacie, poemacie, balladzie w filmie - Październik jawi się jako nowa forma utworu filmowego - zbiór Essays na cały szereg tematów tworzących Rewolucję Październikową. [...] Tutaj już styk z zupełnie nowymi perspektywami filmowymi i przebłyski możliwości, które w zakończonej formie pojawią się w nowym utworze - KAPITAE według libretta Karola Marksa. Filmowy traktat [Kinotraktat - przyp. T.S. $]^{6}$.

Ewolucja filmowej twórczości reżysera jest jak najściślej powiązana z przemianami jego światopoglądu. Już na etapie pracy w Proletkulcie, w pierwszej połowie lat dwudziestych, Eisenstein zaczyna studiować marksizm. Ten rodzaj jego zainteresowań należy bez wątpienia kojarzyć przede wszystkim z duchem czasu, który wyrażał się w atmosferze gorących sporów wokół metod, zadań i celów filo-

5 W tym miejscu warto przytoczyć opinię Josifa Brodskiego: „To, co w podręcznikach historii nazywają Wielką Socjalistyczną Rewolucją Październikową, w rzeczywistości było zwykłym przewrotem, zresztą bezkrwawym. [...] Czerwonogwardziści nie napotkali oporu; zgwałcili połowę ochraniającego pałac kobiecego batalionu i nakradli się po pokojach. Dwóch z nich przy tym zastrzelono, a jeden utopił się w piwnicy z winem. Prawdziwa strzelanina na Placu Pałacowym, kiedy padali zabici i światła reflektorów krzyżowały się na niebie, nastąpiła znacznie później, w reżyserii Siergieja Eisensteina" - J. Brodski, Dyptyk petersburski, czyli przewodnik po przemianowanym mieście, przeł. P. Hertz, A. Husarska, Warszawa 2003, s. 22.

6 S. Ejzensztiejn, op. cit., s. 57.

Prace Kulturoznawcze 22, 2018, nr 3

(C) for this edition by CNS 
zofii marksistowskiej, jakie wywiązały się w tym okresie w porewolucyjnej Rosji. W tych polemikach, których główną platformą były łamy otwartego w 1922 roku pisma filozoficznego i społeczno-ekonomicznego „Pod sztandarem marksizmu”, starły się dwa obozy: mechanicystów i dialektyków. Zwyciężają dialektycy pod wodzą Abrama Deborina. Eisenstein z całą pewnością śledził koleje tej pryncypialnej kontrowersji, o czym świadczą jego artykuły z tego okresu (między innymi sformułowany z okazji Strajku manifest programowy pt. Przyczynek do materialistycznego ujęcia formy w filmie). W 1925 roku pojawia się rosyjski przekład Dialektyki przyrody Engelsa, opublikowano fragment Zeszytów filozoficznych Lenina pt. W sprawie dialektyki oraz książkę Anatolija Łunaczarskiego Od Spinozy do Hegla. Lektury te trafiają na biurko reżysera, a ich marginesy zapełniają się licznymi uwagami. Zresztą młody Eisenstein uważał, że był marksistą jeszcze przed podjęciem systematycznych studiów w tym zakresie, lecz — niczym molierowski pan Jourdain — nie zdawał sobie z tego sprawy:

Prawie anegdota: moi uczniowie z Proletkultu wielokrotnie zwracali mi uwagę, że to, co głoszę, jest bardzo bliskie temu, co oni słyszą w kółku marksistowskim. [...] Teraz pozostało jedynie „nazwać” po imieniu szereg pojęć i rozeznać się w ,istocie” zasad innych zjawisk i systemów”.

Ta droga rozwoju twórczej biografii Eisensteina również prowadziła bezpośrednio do Kapitału. Nie tylko z tego oczywistego powodu, że było to podstawowe dzieło marksizmu, ale przede wszystkim dlatego, że zademonstrowaną w nim metodą poznania rzeczywistości społeczno-ekonomicznej była dialektyka. Zasadniczą intencją tego projektu nie była bowiem adaptacja Kapitału w tradycyjnym rozumieniu tego pojęcia, ponieważ przedmiotem przekładu na język filmu nie był utwór literacki, a naukowy traktat. Eisenstein nie szukał w Kapitale inspiracji artystycznej, lecz metodologicznej. Pod datą 4 kwietnia 1928 roku zanotował: „Dzisiaj sformułowano treść Kapitału (jego orientację): nauczyć robotnika myśleć dialektycznie. Pokazać metodę dialektyki”. A dwa tygodnie później: „Najważniejsze zadanie w kulturalnej rewolucji — nie tylko dialektyczny pokaz, lecz uczenie dialektycznej metody"8.

Dialektyka była dla Eisensteina nie tylko podstawową metodą poznania rzeczywistości, ale również fundamentem jego filmowej estetyki. Fundamentem w najściślejszym tego słowa znaczeniu. W drugiej połowie lat trzydziestych, kiedy teoria Eisensteina zaczyna przybierać charakter systemowy, szkicuje on na

7 S. Ejzensztiejn, (Czto mnie dat W. I. Lenin?) Otwiet na ankietu, [w:] idem, Izbrannyje proizwiedienija w szesti tomach, red. S. Jutkiewicz, Moskwa 1964-1971, t. 5, s. 531. Kwestią nierozstrzygalną pozostaje autentyzm ideologicznego zaangażowania Eisensteina w marksizm, ale jeśli zaufać opinii Jurija Łotmana, wyrażonej w rozmowie ze mną w Moskwie, 1 czerwca 1977 roku, to wynikało ono z oportunizmu, uwarunkowanego duchem porewolucyjnej epoki. Jurij Michajłowicz - zastrzegając, iż nie jest specjalnym znawcą twórczości Eisensteina — suponował, że „on naciągał na siebie ów materializm dialektyczny, tak jak oni wszyscy w tamtych latach" (on natiagiwat na siebia etot diamat, tak kak oni wsie w eti gody).

8 S. Ejzensztiejn, Iz raboczich tietradiej ..., s. 60, 67 [wyróż. — T.S.].

Prace Kulturoznawcze 22, 2018, nr 3

(C) for this edition by CNS 
jednym z wykładów w moskiewskiej szkole filmowej gmach estetyki filmu, którego fundament stanowi dialektyka. Dopiero na niej, jako podstawa całej konstrukcji, wspiera się dziedzina nazwana ludzką ekspresją (wyrazitielnost' czełowieka), z której w charakterze czterech filarów, składających się na pojęcie obrazu, wyrastają od lewej do prawej: patos, inscenizacja, kompozycja kadru i komizm. Na drzwiach budowli widnieje napis „montaż”. Nad nimi unosi się trójkątny fronton złożony z socjologii, techniki i emocjonalnego myślenia (czuwstwiennoje myszlienije), które razem tworzą filozofię sztuki. Na szczycie powiewa sztandar metody kina. Na razie jednak, w latach dwudziestych, Eisenstein usilnie pracuje nad zagadnieniami metodyki montażu i dostrzega organiczny związek pomiędzy tą podstawową dla niego metodą filmowej kreacji a dialektyką.

Istota tego związku opiera się na pojęciu konfliktu, który — według Eisensteina — przenika każdą formę artystyczną, w tym również filmowy montaż jako efekt zderzenia z sobą dwóch ujęć. W artykule napisanym po niemiecku w marcu i kwietniu 1929 roku pt. Dramaturgia filmowej formy analizował różne typy konfliktów, jakie zachodzą pomiędzy kolidującymi z sobą ujęciami, i dowodził, że istnieje możliwość „stworzenia takiej samej wizualnej dramaturgii filmu ujętej w równie ścisłe reguły jak istniejąca w filmie skonwencjonalizowana dramaturgia materiału fabularnego" ". Wyrażał przekonanie, że zdefiniowana przez niego, a oparta na konflikcie wizualna dramaturgia filmowej formy montażu może służyć nie tylko konwencji fabularnej, która wpływa — jak sądził — jedynie na emocje odbiorcy, ale może oddziaływać również na bieg jego myśli. Chodziło mu bowiem o nową formę języka filmowego - o „kino czysto intelektualne, które [...] nada bezpośrednie kształty przekazowi idei, systemów i pojęć i tym samym może urzeczywistnić SYNTEZĘ SZTUKI I NAUKI" 10.

Trudno w tym miejscu szerzej analizować teorię i praktykę kina intelektualnego, ponieważ złożył się na nie cały szereg inspiracji płynących z najróżnorodniejszych źródeł i ich analiza wyprowadziłaby nas zbyt daleko poza granice sformułowanego tematu. Jednej wszakże nie sposób pominąć. Mowa o literaturze.

Pracując nad koncepcją kina intelektualnego, Eisenstein uważał, że jest ona rezultatem wkraczania sztuki filmowej w tak zwany „drugi literacki okres rozwoju”. W opublikowanym w amerykańskim miesięczniku filmowym „Close-up” artykule pt. Nowy język kina pisał:

Jeśli w pierwszym literackim okresie kino opierało się na fabularnym, dramatycznym czy epickim doświadczeniu literatury i zapożyczało od niej elementy konstrukcji utworu w całości, to drugi okres wykorzystuje literaturę w innym kierunku — w kierunku jej doświadczenia w zakresie technologii materiałów, którymi ona operuje $\mathrm{e}^{11}$.

9 S. Ejzensztiejn, Dramaturgija kinoformy, [w:] Montaż, red. N. Klejman, Moskwa 2000, s. 526 [wyróż. - T.S.].

10 Ibidem, s. 533.

11 S.M. Eisenstein, The new language of cinematography, „Close-up” maj 1929, s. 10 [wyróż. T.S.].

Prace Kulturoznawcze 22, 2018, nr 3

(C) for this edition by CNS 
Nie chodzi już zatem o imitowanie literackiej kompozycji zdarzeń, czyli o etap osiągnięty przez poetykę filmów Griffitha, lecz o zbadanie możliwości znaczeniowych i ekspresyjnych tworzywa filmowego, wypracowanie reguł filmowego języka, jego mowy i obrazowości. W twórczości Eisensteina pierwszemu okresowi literackiej inspiracji odpowiadał Pancernik „Potiomkin”, natomiast wyrazem nowych poszukiwań usytuowanych na poziomie obrazowego tworzywa był $P a z ́-$ dziernik. Jednakże montażowe eksperymenty przeprowadzone w tym utworze dezintegrowały jego kompozycję dramaturgiczną. Październik był dziełem przełomu.

Utworem konsekwentnie wiernym założeniom nowej metody miał być Kapitat, wzór kina intelektualnego par excellence. Utrwalone w dziennikach notatki na temat tego projektu stanowią pierwsze stadium jego formowania. Eisenstein gromadzi w nich materiał do przyszłego filmu, szkicuje zarysy sytuacji, których społeczno-polityczne znaczenie ilustruje tezy Marksa, rozważa też problemy kompozycyjne.

Oto kilka przykładów ,intelektualnych atrakcjonów” zanotowanych przez Eisensteina dla Kapitału, które dają wyobrażenie o kierunku jego myślenia na temat przyszłego filmu. Pod datą 4 listopada 1927 roku znajdujemy następującą uwagę:

W Ameryce również cmentarze są prywatne. Konkurencja na 100\%. Przekupywanie lekarzy, etc. Konający otrzymują prospekty: „Tylko u nas będziecie mieli wieczny spokój w cieniu drzew i przy szemraniu strumyczka, etc. (dla Kapitału)"12.

Inny obraz:

O bóstwie: niezastąpiony materiał - Aga-chan, doprowadzony do granic cynizmu szamaństwa. Bóg, który skończył oksfordzki uniwersytet. Grający w rugby i w ping-ponga i przyjmujący modlitwy wiernych. A z tyłu stukają rachunki w „,boskiej” buchalterii przyjmującej dary i ofiary. Najlepsza demaskacja tematu kapłaństwa i kultu ${ }^{13}$.

Albo:

Dobry epizod z Paryża. Ofiara wojny. Beznogi na wózku kończy życie samobójstwem — rzuca się do wody. Opowiedział Maks [Sztrauch — przyp. T.S.] na podstawie jakiejś gazety ${ }^{14}$.

W innym miejscu natrafiamy na zilustrowany rysunkiem opis pocztowej skrzynki dla podrzutków, która znajduje się na jednej z ulic w Atenach obok przytułku dla sierot. Zachwycony Eisenstein komentuje: „Absolutnie znakomity materiał, który poddaje się kształtowaniu aż do »krwawej ironii«. Burżuazyjna kultura i filantropia" 15 .

Przykłady te miały stanowić w intencjach Eisensteina wizualną konkretyzację marksistowskiej analizy ustroju kapitalistycznego. „Elementy samej historyjki — uogólnia w pewnym miejscu sens takiego zabiegu — jawią się w większości jako

\footnotetext{
12 S. Ejzensztiejn, Iz raboczich tietradiej..., s. 57.

13 Ibidem, s. 59.

14 Ibidem.

15 Ibidem, s. 67.
} 
elementy na zasadzie kalamburów popychających do abstrakcji i uogólnienia (mechaniczne trampoliny w kierunku wzorców dialektycznego stosunku do zjawisk)"16.

Niekiedy poszczególne epizody rozszerzają swoją objętość — jak na przykład historia żony niemieckiego robotnika, która gotuje zupę. Jej kuchenna zapobiegliwość ma — według Eisensteina — reakcyjny sens społeczny i stanowi najsilniejszy hamulec dla rewolucji w warunkach niemieckich, ponieważ „nigdy nie zostawi ona swojego męża bez gorącego posiłku — definitywnie głodnym"17. Eisenstein był bardzo przywiązany do tego pomysłu, stwarzał on bowiem wiele możliwości asocjacyjnych. Na przykład: „,...asocjacja w trzeciej części filmu idzie od pieprzu, którym ona pieprzy: Pieprz. Cayenne. Diabelska wyspa. Dreyfus. Francuski szowinizm. »Figaro« w rękach Kruppa. Wojna. Zatopione w porcie statki" ${ }^{18}$. W ten sposób banalna sytuacja staje w centrum szerokiego kręgu społeczno-politycznych problemów epoki, związanych z eksploatacją kolonii czy mechanizmami imperialistycznych wojen. „Kiedy ma się taką zupę — pisze Eisenstein — to można do niej włożyć każdy pieprz"19.

Z tego samego obrazu wysnuwa inny ciąg asocjacji, który odkrywa sprzeczność pomiędzy zasadami mieszczańskiej moralności, zasadą zysku za wszelką cenę w produkcji kapitalistycznej i estetycznymi gustami epoki. Z obrazu dziurawej pończochy żony niemieckiego robotnika wynika prawem metonimii obraz jedwabnej pończochy w prasowej reklamie:

Zaczynając tańczyć kankana, rozmnaża się w 50 par nóg - Revue, Jedwab. Sztuka. Walka o centymetr jedwabnej pończochy. Esteci za. Episkopat i moralność przeciw. Mais ces pantins [ale te pajace - przyp. T.S.] tańczą na nitkach fabrykantów jedwabiu i konkurujących z nimi producentów wierzchniej odzieży. Sztuka. Święta sztuka. Moralność. Święta moralność ${ }^{20}$

— konkluduje ironicznie Eisenstein.

Obraz jedwabnej pończochy zaczyna rozszerzać się w zapiskach, powtarzać w różnych kontekstach znaczeniowych, reżyser uważa bowiem, że dialektycznej analizie ekonomiczno-społecznych sprzeczności kapitalizmu najlepiej służy chwyt repetycji, który został już wypróbowany w intelektualnych sekwencjach Października (na przykład w obrazie Kierenskiego na schodach w Pałacu Zimowym). A zatem w notatkach poświęconych Kapitałowi zamierza wykorzystać ten chwyt w sposób bardziej konsekwentny:

Ein Paar seidene Strümpfe [para jedwabnych pończoch — przyp. T.S.] — sztuka. Ein Paar seidene Strümpfe — moralność. Ein Paar seidene Strümpfe — handel i konkurencja. Ein Paar seidene Strümpfe — indyjskie kobiety, które zmuszone są kształtować jedwabne kokony pod pachami ${ }^{21}$.

16 Ibidem, s. 64.

17 Ibidem, s. 63 [wyróż. — T.S.].

18 Ibidem.

19 Ibidem, s. 66.

20 Ibidem, s. 64.

21 Ibidem, s. 66-67 [wyróż. — T.S.].

Prace Kulturoznawcze 22, 2018, nr 3

(C) for this edition by CNS 
Gromadzone przez Eisensteina realia miały na celu swoistą aktualizację dzieła Marksa, które powstawało w latach osiemdziesiątych XIX wieku. Reżyser pragnął oprzeć się na materiale sobie współczesnym, pochodzącym z drugiej połowy lat dwudziestych XX stulecia. 17 marca 1928 roku pisze o tym wprost:

W planie „historycznego materializmu” obróconego na dzień dzisiejszy należy znajdować współczesne ekwiwalenty dla przełomowych momentów epok przeszłości. Na przykład temat tkackich warsztatów i burzycieli maszyn — tkaczy należy pokazać na zderzeniu: elektryczny tramwaj w Szanghaju i tysiące pozbawionych przez to pracy kulisów, którzy kładą się na szyny, aby umrzeć ${ }^{22}$.

W innym miejscu znajdujemy zapis na temat jednej z fabryk, „gdzieś na Zachodzie", w której rewizji robotników przy wyjściu z pracy dokonuje magnetyczna brama ${ }^{23}$.

Przestrzenna skala akcji filmu miała obejmować cały świat: Chiny, Indie, Egipt, obie Ameryki, Europę. Komentując ten globalny rozmach projektu, Eisenstein przywołuje swoją dyskusję na ten temat z Grigorijem Aleksandrowem, swoim asystentem, który był przerażony rozmiarami materiału, a w związku z tym metrażem planowanego filmu:

Chiny, piramidy, Nowy Jork, które tak przestraszyły Griszę, nie są istotą tematu, lecz montażowymi fragmentami dla uporządkowania myśli [...]. Należy pamiętać, że istnieją one nie po to, aby pokazać Chiny, lecz po to, aby poprzez ten fragment w połączeniu z innymi - Nowym Jorkiem, Egiptem — pokazać pewną myśl $1^{24}$.

Nowatorstwo tego typu konstrukcji montażowej polegało - według Eisensteina — na tym, że podczas gdy „antyczne kino” filmowało jedną akcję z wielu punktów widzenia, to nowe montuje jeden punkt widzenia $\mathrm{z}$ wielu akcji. Jest to punkt widzenia idei.

Jak przedstawiał się plan organizacji całego materiału, zarys kompozycji filmu, dramaturgiczny szkic scenariusza? Jest to zagadnienie, które nie znajduje w tych lakonicznych uwagach jednoznacznego rozwiązania. Oświetla jednak zasadnicze dylematy, które stawiał ten problem przed autorem przyszłego filmu. Pod datą 4 kwietnia 1928 roku czytamy charakterystyczne wyznanie: „Jeszcze bardzo trudno myśleć jakąś »pozafabularną《 obrazowością. Ale to nie zmartwienie - ça viendra! [to nastąpi - przyp. T.S.]" 25 . W planie czysto konceptualnym film według Kapitału miał składać się z kilku rozdziałów poświęconych między innymi dialektycznej analizie zjawisk historycznych, dialektyce w naukach przyrodniczych i materialistycznemu pojmowaniu historii. Ostatni rozdział miał traktować o dialektyce walki klasowej.

\footnotetext{
22 Ibidem, s. 59.

23 Ibidem, s. 60.

24 Ibidem, s. 62 [wyróż. — T.S.].

25 Ibidem, s. 60.
} 
Eisenstein marzył o filmowym traktacie na filozoficzne i społeczno-ekonomiczne tematy, jednakże zdawał sobie sprawę, że całkowite odejście od poetyki kina fabularnego nie jest możliwe. Zależało mu jednak na znalezieniu fabuły bardzo stereotypowej, banalnej i wątłej zarazem. Akceptację fabularnej konieczności uważał za kompromis: „Jedyną kwestią pryncypialną z minionej epoki będzie przyjęcie i tutaj zasady: »Filmowy jest ten utwór, którego fabuła może być opowiedziana w dwóch słowach «"26.

I rzeczywiście, reżyser znajduje taką fabułę. Podpowiada mu ją Ulisses Jamesa Joyce'a. Pretekstem fabularnym intelektualnej akcji Kapitału miał być bowiem jeden dzień z życia człowieka. Podobnie jak w Ulissesie. W okresie koncepcyjnej pracy nad Kapitałem Eisenstein miał okazję zapoznać się z tym dziełem ${ }^{27}$. Jego fascynacja metodą Joyce'a wynikała przede wszystkim z poczucia niezwykłej zbieżności pomiędzy własnymi ideami konceptualizacji wizualnego tworzywa filmu a literackimi technikami eksploracji ludzkiej świadomości i podświadomości stosowanymi przez irlandzkiego pisarza. Zbieżność ta podyktowała Eisensteinowi dedykację przyszłego filmu: „Formalną stronę poświęca się Joyce’owi”28.

Mimo kilkakrotnie podkreślanej w notatkach poświęconych Kapitałowi więzi tego zamysłu z metodą Joyce'a Eisenstein nie zapomina o zaznaczeniu fundamentalnej różnicy pomiędzy swoim projektem a Ulissesem. Joyce opisując wydarzenia jednego dnia z życia swojego bohatera, akwizytora ogłoszeniowego Leopolda Blooma, próbuje przeniknąć w głąb jego psychiki, natomiast projektodawcę filmowego Kapitału interesuje związek powszednich zdarzeń w codziennym życiu jednego człowieka z procesami społeczno-ekonomicznymi epoki, w której żyje, a indywidualna psychologia jednostki staje się dla niego wyrazem dziejowej prawidłowości. Słowem — jeśli Joyce opisuje świat w człowieku, to Eisenstein zajmuje się człowiekiem w świecie. Jednakże reżyser nie rozwija w swoich koncepcyjnych szkicach istoty tego związku, nie analizuje motywacji roli fabularnego schematu w stosunku do zgromadzonych realiów, detali, postaci czy sytuacji i stąd trudno wyobrazić sobie na podstawie tego stadium projektu artystyczną logikę tej dialektycznej syntezy pomiędzy codziennością ludzkiego losu a społecznymi prawami rozwoju kapitalistycznego świata.

Jak wiadomo, Eisenstein Kapitatu nie zrealizował. Oksana Bułgakowa, jego biografka, przywołuje z archiwum świadectwo reżysera: „Wczoraj widziałem

26 Ibidem, s. 62.

27 W dziennikach Eisensteina pod datą 15 lutego 1928 można znaleźć zapis: „W sobotę dostałem Ulissesa, nową Biblię filmu”. Autorski egzemplarz od Joyce'a z jego dedykacją przekazała mu Angielka Ivy Low, żona ówczesnego wicekomisarza spraw zagranicznych, Maksima Litwinowa (zob. G. Werner, James Joyce och Sergej Eisenstein. Två konstnärers möte, Lund 1988, s. 12, 41; S.M. Eisenstein, Schriften 3. „, Oktober”. Mit den Notaten zur Verfilmung von Marx' ,, Kapital”, red. H.-J. Schlegel, München 1973-1975, s. 368).

28 S. Ejzensztiejn, Iz raboczich tietradiej..., s. 65. 
się z Podwojskim. Jest przeciw Kapitałowi"29. Gorzej, że przeciw był również ktoś nieskończenie potężniejszy od bolszewickiego dygnitarza, który był jednym z przywódców szturmu na Pałac Zimowy i zagrał samego siebie w Październiku. Michaił Blejman wspominał, powołując się na rozmowę z Eisensteinem, że wiosną 1929 roku Stalin dowiedziawszy się od niego, iż zamierza sfilmować Kapitat, krzyknął: „Oszalał!” (S uma soszoł!) ${ }^{30}$, co oczywiście projekt unicestwiło.

Niezależnie od werdyktu dyktatora, przesądzającego o losie przyszłego filmu, warto również zwrócić uwagę na wewnętrzne, wynikające z ewolucji sztuki filmowej, przyczyny upadku tego zamysłu. Po ukończeniu Października reżyser wrócił do realizacji Linii generalnej (Gieneralnaja linija ${ }^{31}$, 1929), którą rozpoczął jeszcze w 1926 roku. Ważniejsze jednak wydają się nowe perspektywy rozwoju języka filmowego, odkryte przez wprowadzenie techniki dźwiękowej, które pogłębiłyby możliwości kina w urzeczywistnieniu tak skomplikowanego zadania, a które nie były wystarczająco opanowane w tym okresie. W celu zgłębienia tajników kina dźwiękowego Eisenstein wyjeżdża w sierpniu 1929 roku wraz ze swoimi najbliższymi współpracownikami, operatorem Eduardem Tisse i asystentem Grigorijem Aleksandrowem, na Zachód Europy, gdzie wygłasza wykłady poświęcone teorii kina intelektualnego, a następnie do Stanów Zjednoczonych, aby podejmować cały szereg pomysłów, w których można odnaleźć ideowe dziedzictwo Kapitału. Tematy jego niezrealizowanych w Hollywood filmów zostają bowiem wywiedzione z Marksowskiej analizy ustroju kapitalistycznego. Cykl projektów amerykańskich — Glass House, Złoto Suttera, Amerykańska tragedia czy Zmierzch bogów - jednoczył wspólny temat, który Eisenstein określił mianem „tragedii indywidualizmu” zawinionej przez kapitalistyczne warunki społecznego bytu. Filmem szczególnie bliskim Kapitałowi ze względu na ideowe intencje miało być Złoto Suttera. Jego scenariusz został napisany na podstawie powieści Blaise’a Cendrarsa i był poświęcony przedstawieniu — na przykładzie losu kalifornijskiego odkrywcy złota - dialektyki rozwoju ustroju kapitalistycznego, który od postępowej formy gospodarki przechodzi do zburzenia stworzonej w swoich ramach cywilizacji.

Kapitał był jedną z utopii artystycznych Eisensteina, które stanowiły wyprawy do wyobrażonych przezeń granic kina. Te samotne podróże stawały się częstokroć przedmiotem prowokowanych ataków. Przypomnijmy nader znamienną

29 O. Bulgakowa, Sergei Eisenstein. A Biography, przeł. A. Dwyer, Berlin-San Francisco 1998, s. 90 .

30 N. Klejman, op. cit., s. 12. Oficjalne stanowisko w tej sprawie przedstawia fragment artykułu Eisensteina w odpowiedzi na ankietę Co mi dat W.I. Lenin: „Szereg niezbędnych teoretycznych przeróbek, poprzedzających przystąpienie do takiego »Magnitogorska« kinematografii, i związana z tym osobista wskazówka tow. Stalina (w rozmowie z nim wiosną 1929 roku) na temat zadań ważniejszych wymusiły tymczasowe odłożenie realizacji tego zadania" — S. Ejzensztiejn, (Czto mnie dat W.I. Lenin?) Otwiet na ankietu..., s. 534.

31 Premiera filmu odbyła się pod zmienionym tytułem Stare i nowe (Staroje i nowoje).

Prace Kulturoznawcze 22, 2018, nr 3

(C) for this edition by CNS 
odpowiedź Eisensteina na jeden z nich. Na przełomowej dla kinematografii radzieckiej, a dramatycznej dla Eisensteina, I Wszechzwiązkowej Naradzie Pracowników Kinematografii w 1935 roku tak odpierał on zarzuty Siergieja Wasiliewa, opromienionego niedawnym sukcesem Czapajewa (Czapajew, 1934), który uznano za wzór proklamowanego na tym zjeździe kina socrealistycznego:

Kiedy ty mówisz o moim chińskim chałacie, w którym ja jakoby siedzę w swoim gabinecie, to popełniasz omyłkę: na nim nie ma hieroglifów. I ja nie na statuetki spoglądam i abstrakcyjnie kontempluję, kiedy siedzę w gabinecie. Ja pracuję nad problemami, które zostaną podsunięte dorastającej młodzieży filmowej. I jeśli ja siedzę i pracuję w gabinecie, to po to, abyś ty nie tracił czasu w gabinetach, a mógł dalej tworzyć tak wspaniałe filmy jak twój Czapajew ${ }^{32}$.

Jest to wypowiedź niezwykle znamienna dla Eisensteinowskiego myślenia o sztuce, dla jego metody twórczej. Jego twórczości często zarzucano zbyt ścisły związek z teorią, akademicki intelektualizm i kompulsywną precyzję formalną. On sam zdawał sobie sprawę $\mathrm{z}$ tej skrajności, lecz w tym teoretycznym szaleństwie była metoda, którą nazywał „dokręcaniem mechanizmu eksperymentu do końca” po to, aby inni mogli go — jak pisał — „,cofnąć o pół obrotu” 33 i zastosować w swojej twórczości. I podobnie jak Wielemira Chlebnikowa nazywano „poetą dla poetów”, tak Eisensteinowi przysługiwałoby miano „reżysera dla reżyserów".

Z lektury notatek szkicujących wstępny kształt Kapitału na ekranie wynika również konkluzja metodologiczna dla historyka filmu. Wydobyty z archiwum niespełniony zamysł Eisensteina okazuje się nie mniej istotny dla rekonstrukcji poetyki jego twórczości aniżeli jego filmy zrealizowane, szczęśliwie ukończone, które figurują na rozmaitych ,złotych listach” historii kinematografii. W nim bowiem konkretna koncepcja artystyczna zyskała kształt znacznie bardziej wyrazisty, zdeterminowany i bezkompromisowy aniżeli w jej ekranowych realizacjach, które ulegały ograniczeniom, częstokroć niezależnym od woli artysty.

\section{"He went crazy!": Sergei Eisenstein prepares the adaptation of The Capital by Karl Marx}

Abstract

This article is an analysis of a legendary creative project of Sergei Eisenstein, who at the end of the 1920s was thinking about filming Capital: A Critique of Political Economy by Karl Marx. For years this idea was regarded as anecdotal empty bragging of the eminent director, but his journals from the years 1927-1928 include materials proving that the conceptual work on the film was at an advanced stage. The main idea behind the film fully developed the concept of the so-called intel-

32 S. Ejzensztiejn, Wystuplienije na Wsiesojuznom Tworczeskom Sowieszczanii Robotnikow Sowietskoj Kiniematografii, [w:] idem, Izbrannyje proizwiedienija ..., t. 2, s. 128.

33 Ibidem.

Prace Kulturoznawcze 22, 2018, nr 3

(C) for this edition by CNS 
lectual cinema as an ideological discourse, with which Eisenstein had already experimented when making October: Ten Days That Shook the World. The author of the article sets young Eisenstein's working notes on the film version of Capital in the context of his interest in Marxism and in the political and propaganda context of his cinema's evolution in the 1920s, also explaining the reasons for the failure of the project, the theme and ideology of which were to some extent reflected in Eisenstein's unfinished Hollywood projects.

Keywords: Marxism, Capital, intellectual cinema, James Joyce

\section{Bibliografia}

Blejman M., Płodotwornost', oszibki”, „Iskusstwo Kino” 1973, nr 1.

Brodski J., Dyptyk petersburski, czyli przewodnik po przemianowanym mieście, przeł. P. Hertz, A. Husarska, Warszawa 2003.

Bulgakowa O., Sergei Eisenstein. A Biography, przeł. A. Dwyer, Berlin-San Francisco 1998.

Eisenstein S.M., The new language of cinematography, „Close-up” maj 1929.

Eisenstein S.M., Schriften 3. ,, Oktober”. Mit den Notaten zur Verfilmung von Marx',, Kapital”, red. H.-J. Schlegel, München 1973-1975.

Ejzensztiejn S., (Czto mnie dat W. I. Lenin?) Otwiet na ankietu, [w:] idem, Izbrannyje proizwiedienija w szesti tomach, red. S. Jutkiewicz, Moskwa 1964-1971.

Ejzensztiejn S., Dramaturgija kinoformy, [w:] Montaż, red. N. Klejman, Moskwa 2000.

Ejzensztiejn S., Izbrannyje proizwiedienija w szesti tomach, Moskwa 1964-1971.

Ejzensztiejn S., Iz raboczich tietradiej 1927-28 godow, „Iskusstwo Kino” 1973, nr 1.

Ejzensztiejn S., Wystuplienije na Wsiesojuznom Tworczeskom Sowieszczanii Robotnikow Sowietskoj

Kiniematografii, [w:] idem, Izbrannyje proizwiedienija w szesti tomach, t. 2, Moskwa 1964.

Klejman N., Nieosuszczestwlionnyje zamysty Ejzensztiejna, „Iskusstwo Kino” 1992, nr 6.

Moussinac L., S. M. Eisenstein, Paris 1964.

Werner W., James Joyce och Sergej Eisenstein. Två konstnärers möte, Lund 1988. 